\title{
Physiological and Endocrinological Responses During Prolonged Exercise in Hatchery-Reared Rainbow Trout (Oncorhynchus mykiss)
}

\author{
By M. E. Nielsen ${ }^{I}$, L. Boesgaard ${ }^{I}$, R. M. Sweeting ${ }^{2}$, B. A. McKeown ${ }^{2}$ and P. Rosenkilde ${ }^{3}$
}

\begin{abstract}
${ }^{1}$ Department of Veterinary Microbiology, Section of Fish Diseases, The Royal Veterinary and Agricultural University, Frederiksberg, Denmark, ${ }^{2}$ Department of Biological Sciences, Simon Fraser University, Burnaby, British Columbia, Canada, ${ }^{3}$ Zoophysiological Laboratory, August Krogh Institute, University of Copenhagen, Denmark.
\end{abstract}

\begin{abstract}
Nielsen ME, Boesgaard L, Sweeting RM, McKeown BA, Rosenkilde P: Physiological and endocrinological responses during prolonged exercise in hatchery-reared rainbow trout (oncorhynchus mykiss). Acta vet. scand. 2000, 41, 173-184. - Rainbow trout (Oncorhynchus mykiss) were subjected to vigorous exercise (1.5 body length $\left.\mathrm{s}^{-1}\right)$, low exercise $\left(0.5\right.$ body length $\left.\mathrm{s}^{-1}\right)$ or still-water $\left(0.0\right.$ body length $\left.\mathrm{s}^{-1}\right)$. Hematocrit, glucose, growth hormone $(\mathrm{GH})$, cortisol and triiodo-L-thyronine $\left(\mathrm{T}_{3}\right)$ were monitored at the start of exercise, after $24 \mathrm{~h}$, and after 2, 4, 8, 16 and 32 days of continuous swimming. Morphological indices and food intake were also monitored. At the end of the experiment, trout subjected to low exercise had gained significantly $(\mathrm{p}<0.05)$ more weight than both the control (still-water) and vigorously exercised fish. This low exercised group of fish also consumed more food than the 2 other groups. Hematocrit increased significantly in both exercised groups at the onset of swimming but returned to pre-exercise levels within $8 \mathrm{hrs}$. Plasma glucose appeared to be generally unaffected by exercise. Likewise, plasma concentrations of both $\mathrm{GH}$ and $\mathrm{T}_{3}$ were not influenced by exercise. Plasma cortisol levels increased in an exercise dependent fashion at the onset of swimming, but returned to pre-swimming levels within $24 \mathrm{~h}$ and there was no apparent effect of sustained swimming. The results suggest: (i) the onset of exercise elicits transient changes in plasma components, (ii) the observed weight gain in low exercising salmonids occur without increases in circulating levels of $\mathrm{GH}$ or $\mathrm{T}_{3}$.
\end{abstract}

Cortisol; Growth hormone; $T_{3}$; Hematocrit; Fish growth; Exercise; Rainbow trout.

\section{Introduction}

During the last decades, several studies have demonstrated that salmonids continuously exercised at modest speeds $(1.0-2.0$ body lengths $\mathrm{sec}^{-1}$; BLS) may show increased growth compared to non-exercised controls (Walker \& Emerson 1978, Houlihan \& Laurent 1987, Totland et al. 1987, Christiansen \& Jobling 1990, Davidson 1997). In addition to the generally improved fitness (East \& Magnan 1987), the increased growth observed in these and other studies has been attributed to increases in both food consumption (Leon 1986, Totland et al. 1987) and food conversion efficiency (Kuipers 1982, Leon 1986, Davidson 1997). However, while several experiments have dealt with these general factors, few have investigated the changes in hormonal and other regulatory factors during long-term exercise.

Increase in appetite or food consumption and food conversion efficiency are 2 functions 
which, in teleosts as well as in other vertebrates, are known to be modulated by the growth hormone (GH) (Weatherley \& Gill, 1989, Björnsson 1997) in addition to its effect on growth and protein synthesis (McKeown et al. 1975, Weatherley \& Gill 1982, Gill et al. 1985, McLean et al. 1990, Foster et al. 1991). Furthermore, during sustained swimming, rainbow trout (Oncorhynchus mykiss) preferentially mobilize lipid reserves and conserve body protein (Beamish 1978), and several studies have demonstrated the important lipolytic role played by the growth hormone in salmonids (McKeown et al. 1975, Sheridan 1986, 1994, Björnsson 1997). Finally Barrett \& McKeown (1988) and Kakizawa et al. (1995) have shown that plasma concentrations of the growth hormone were highly elevated in steelhead salmon (Oncorhynchus mykiss) following $24 \mathrm{~h}$ of exercise at high speeds (1.5 BLS). However, these studies measured plasma hormone concentrations post-exercise and little information exists on growth hormone levels during either short term or long term exercise in fish.

Although growth promotion has most frequently been associated with $\mathrm{GH}$, thyroid hormone is also involved in growth promotion (Higgs et al. 1977). Furthermore, 3,5,3'-triiodo-L-thyronine (T3), the more potent form of the thyroid hormone (Eales 1985), has been shown to stimulate transcription of growth hormone mRNA (Moav \& McKeown 1992) and thus, indirectly, stimulate growth. GH has also been implicated in the regulation of $\mathrm{T}_{3}$ production (MacLatchy et al. 1992). Thus thyroid and growth hormone may be interacting in exercised fish. However, there is limited information in the literature on links between exercise, growth and the thyroid hormone.

In contrast to the anabolic actions of both growth hormone and $\mathrm{T}_{3}$, the actions of cortisol are generally considered to be catabolic and growth suppressive (Barton et al. 1987, Picker- ing 1990). The imposition of an exercise regime on fish might be considered a stress challenge (Boesgaard et al. 1993) the degree depending upon the velocity of the water current the fish is forced to swim against (Nielsen et al. 1994). Furthermore, the catabolic actions of cortisol may provide sources of energy for the increased metabolism associated with swimming against even a moderate current. A few studies have examined the effects of exercise on subsequent stress challenges, for instance osmoregulation (Postlethwait \& McDonald 1995, Mommsen 1999), but little is known about the possible alterations in plasma cortisol levels.

The aim of this study was to investigate possible correlations between improved growth and involved hormonal factors $\left(\mathrm{GH}, \mathrm{T}_{3}\right.$ and cortisol) in rainbow trout subjected to vigorous exercise (1.5 BLS), low exercise (0.5 BLS), or still-water (0.0 BLS) for a period of 32 days. The level and length of the exercise periode were chosen to prevent induction of anaerobic white muscle work (Johnston \& Moon 1980). Whereas most of the previous work on exercise in fish has focused on post-exercise effects, this study was designed to obtain better insight into metabolic and endocrine parameters during low and vigorous exercise. Therefore, food intake and growth (weight, length and condition factor) were correlated with levels of $\mathrm{GH}$, thyroid hormone and cortisol plus hematocrite and blood glucose. The food intake of the fish was carefully measured during the study to determine possible changes in appetite.

\section{Materials and methods \\ Fish}

Juvenile $1+$ rainbow trout $(\mathrm{n}=540)$; mean weight $94.5 \pm 1.3 \mathrm{~g}$; mean length $20.4 \pm 0.1 \mathrm{~cm}$ fork length) were obtained from the West Creek Hatchery, Langley, British Columbia, Canada, from a strain selected for 8 generations for fast growth in a low water current environment ( $A$. 
Ludwig, pers. comm). The fish were distributed equally $(n=160)$ in three 20001 fibreglass oval raceways and acclimated for 2 weeks under natural photoperiod and temperature $\left(10-11^{\circ} \mathrm{C}\right)$. Each raceway was supplied with a constant flow of oxygenated and de-chlorinated tap water $\left(300-\mathrm{L} \mathrm{h} \mathrm{h}^{-1}\right)$. The raceways had 2 straight fenced-in sections (each with a volume of 600 1) in which trout $(\mathrm{n}=80)$ were kept (McKinnon $\&$ Farrell 1992). During the two-week acclimation period, the fish were hand fed $1 \%$ of body weight per day with commercial trout pellets (Nelsons Sterling Silver Cup).

On day 0 of the study, water flow was created by a 24-volt electric outboard motor in 2 of the 3 raceways. One raceway had a water current set at approximately $0.1 \mathrm{~m} \mathrm{~s}^{-1}$ (corresponding to 0.5 BLS) while the other raceway had a water current of approximately $0.3 \mathrm{~m} \mathrm{~s}^{-1}$ (corresponding to $1.5 \mathrm{BLS}$ ), subsequently referred to as the low and the vigorously exercised groups, respectively. The fish referred to as the still-water or control group were maintained in standing water (0.0 BLS). During the 32 days of exercise, the fish of each raceway were carefully fed to satiation twice daily. In this way it was possible to estimate the amount of food given to each group and thereby get an overall impression of appetite.

\section{Raceway design}

In designing the chambers and raceways, there was a conscious attempt to minimise turbidity or other variations in water-flow (McKinnon \& Farrell 1992). It should be noted that while the still-water fish were not forced to swim against a current, these fish exhibited normal random swimming tendencies and thus cannot be designated as non-active.

\section{Sampling}

Sampling occurred immediately before the onset of exercise (time $=0$ ), at 1, 2, 4, 8 and $24 \mathrm{hrs,}$ and after 2, 4, 8, 16 and 32 days of exercise. To minimise any effects of diurnal changes on plasma parameters, sampling always started at 9 a.m. (except over the initial 24 h). At each sampling time, 8 fish were rapidly netted and lethally anaesthetised with neutralised MS-222 (Syndel Labs., BC., Canada). All fish were unconscious within 10-15 sec. Blood was collected from the caudal vein in heparinized syringes, dispensed into $1.5 \mathrm{ml}$ microcentrifuge tubes and immediately placed on ice. Complete sampling procedure (netting, weights and blood collection of all fish) was performed within 8$10 \mathrm{~min}$. Blood samples were centrifuged ( $5 \mathrm{~min}$ $\times 16000 \mathrm{~g}$ ), hematocrits recorded and plasma components stored at $-20^{\circ} \mathrm{C}$ until further analysis. Fork length, liver weights and mesenteric fat content were obtained following completion of sampling (carcasses stored on ice). Extreme care was taken to minimise stress during each of the sampling periods. Furthermore, fish from each consecutive sampling were taken from the alternate chamber of the appropriate raceway, thus allowing a period of recovery for the remaining fish and minimising stress from the previous sampling period.

\section{Analysis}

Body wet weights and fork lengths were obtained for all fish at each sampling period. Mean liver weight and weight of mesenteric fat was determined at $0,2,4,6,16$ and 32 days. Plasma growth hormone levels were determined in triplicates by radio-immuno-assay (RIA) for salmon GH essentially as described by Sweeting et al. (1985) but with the following differences: (i) both the GH standards and the radiolabelled [ $\left.{ }^{125} \mathrm{I}\right]-\mathrm{GH}$ were stored in acetate buffer $(0.2 \mathrm{M}$ with $0.5 \% \mathrm{BSA}$; $\mathrm{pH} 5.0)$, (ii) the final precipitating buffer contained $4.0 \%$ PEG (polyethylene glycol, Sigma, USA). Plasma 3.5.3'-triiodo-L-thyronine was determined in duplicates by a commercial RIA (Gamma- 
Table 1. Morphological data for rainbow trout exercised at 0.0 (Control), 0.5 (Low exercise) or 1.5 (Vigorous exercise) body lengths $\mathrm{sec}^{-1}$ for 32 days. Each value represents means $(\mathrm{n}=8) \pm$ SEM. $\left({ }^{*}\right)$ Represent a significant difference from Day 0 . Values with different letters are significantly different from each other.

\begin{tabular}{lllllc}
\hline \multirow{2}{*}{ Group } & \multicolumn{2}{c}{ Day 0 } & & \multicolumn{2}{c}{ Day 32 } \\
\cline { 2 - 3 } & Weight $(\mathrm{gms})$ & Length $(\mathrm{cm})$ & & Weight $(\mathrm{gms})$ & Length $(\mathrm{cm})$ \\
\hline Controls & $98.46(4.18)$ & $21.29(0.17)$ & & $119.2^{\mathrm{a}}(14.14)$ & $21.88^{*}(0.57)$ \\
Low Exercise & $96.07(3.28)$ & $20.76(0.27)$ & & $154.29^{* \mathrm{~b}}(10.51)$ & $22.78^{*}(0.68)$ \\
Vigorous Exercise & $96.83(4.34)$ & $21.63(0.25)$ & & $111.29^{* \mathrm{a}}(12.05)$ & $21.48^{*}(0.39)$ \\
\hline
\end{tabular}

CoatTM [ ${ }^{125}$ I] T 3 RIA Kit, INCSTAR Corporation, USA) The limit of detection of this RIA was $0.5 \mathrm{ng} \mathrm{ml}^{-1}$. Plasma cortisol values were determined in triplicates using a commercial ELISA kit (Diagnostic Systemes Laboratories, USA) with a detection limit at $2 \mathrm{ng} \mathrm{ml}^{-1}$. Duplicates of plasma glucose titers were analysed colorimetrically (\#16UV, Sigma, USA).

\section{Statistical analysis}

Data were analysed using two-way analysis of variance (ANOVA, Sheffe F-test) with treatment and time as factors. In each group postexercise values ( 32 days) were compared to preexercise values ( 0 days) using Student's $t$-test. Significant differences were accepted at the

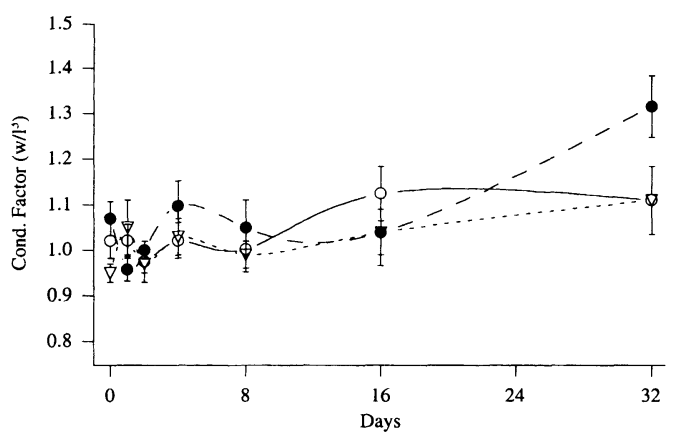

Figure 1. Condition factor $\left(\mathrm{w} / \mathrm{l}^{3}\right)($ mean $\pm \mathrm{SEM})$. (O) Control group $(n=6-8)$; ( $(\bullet$ Low exercised trout $(\mathrm{n}=8) ;(\nabla)$ Vigorously exercised trout $(\mathrm{n}=8)$. probability level of 0.05 . All data are given as arithmetic means \pm S.E.M.

\section{Results}

No mortality was observed in any of the exercise groups throughout the study. Furthermore, no fish were at any time obviously fatigued by the continuous enforced exercise. Thus, there were no observations of fish "resting" against the back of the holding chamber.

All 3 groups showed a significant increase in length from 0 to 32 days (Table 1), but there were no significant differences between the groups at 32 days. Both exercise groups showed significant increases in weight from 0 to 32 days, but the low exercised fish had signifi-

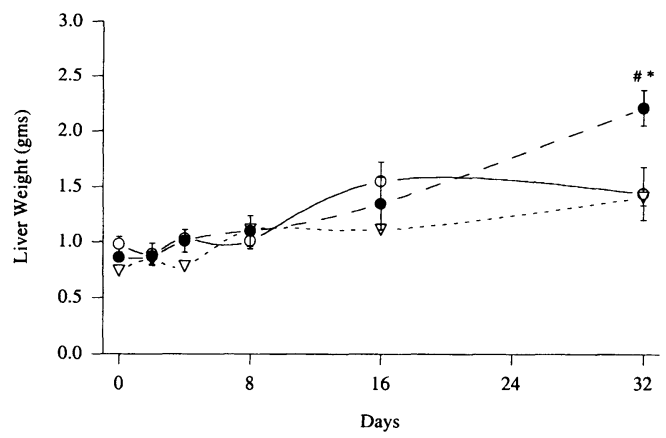

Figure 2. Liver weight in gram (mean \pm SEM). (O) Control group $(\mathrm{n}=8) ;(\bigcirc)$ Low exercised trout $(\mathrm{n}=$ $8) ;(\nabla)$ Vigorously exercised trout $(n=8)$. 


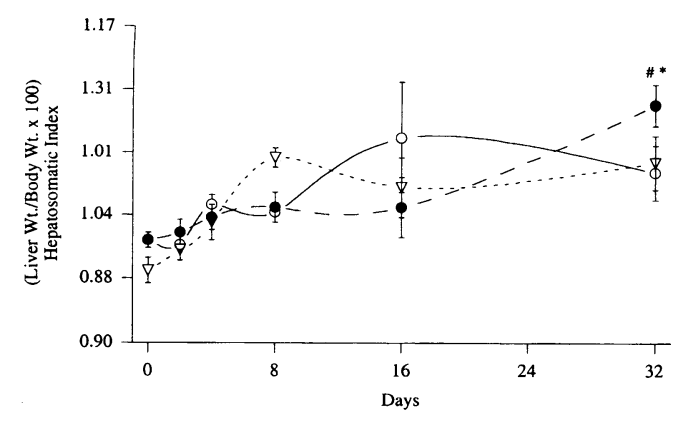

Figure 3. Hepatosomatic index (liverweight in percent of body weight). ( $O$ ) Control group $(n=8) ;(\bullet)$ Low exercised trout $(\mathrm{n}=8) ;(\nabla)$ Vigorously exercised trout $(\mathrm{n}=8)$. $\left({ }^{*}\right)$ Different from vigorously exercised trout and control group. (\#) Represent a significant difference from Day 0 .

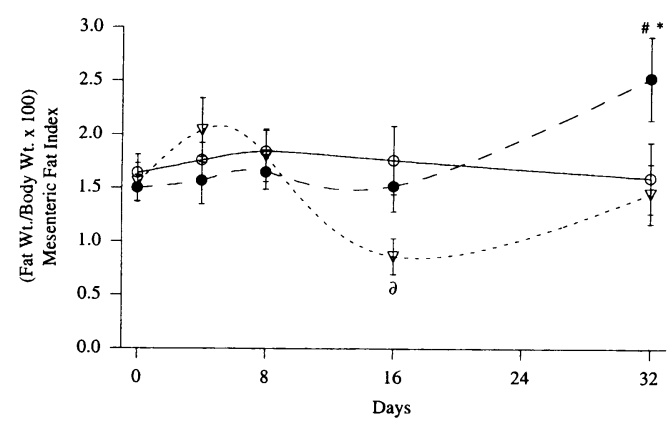

Figure 5. Mesenteric fat index (mesenteric fat index in percent of body weight). (O) Control group $(\mathrm{n}=8)$; $(\bullet)$ Low exercised trout $(\mathrm{n}=8) ;(\nabla)$ Vigorously exercised trout $(\mathrm{n}=8)$. $\left({ }^{*}\right)$ Different from vigorously exercised trout and control group. ( $\partial$ ) Different from low exercised trout and control group. (\#) Represent a significant difference from Day 0.

cantly higher mean weights at the end of the study compared to either the still-water group or the vigorously exercised trout. Besides the effects seen directly from increments in length or weight, the condition factor suggests changes in the distribution of the gained body mass (Fig 1).

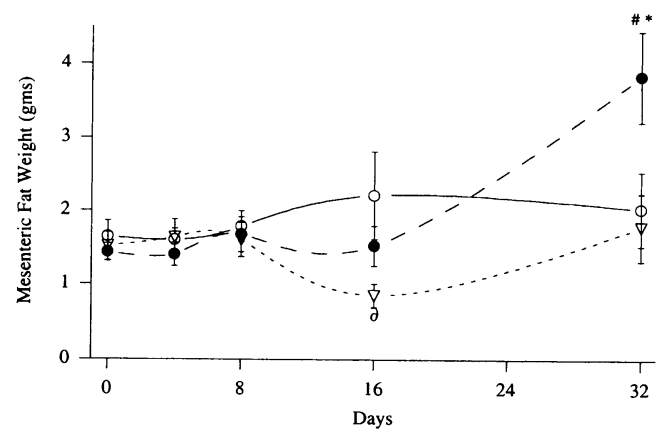

Figure 4. Mesenteric fat weight in gram (mean \pm SEM). (O) Control group $(\mathrm{n}=8) ;(\bullet)$ Low exercised trout $(\mathrm{n}=8) ;(\nabla)$ Vigorously exercised trout $(\mathrm{n}=8)$. $\left(^{*}\right)$ Different from vigorously exercised trout and control group. (Ә) Different from low exercised trout and control group. (\#) Represents a significant difference from Day 0.

Table 2. Average weight gain, food consumption and utilisation of rainbow trout for rainbow trout exercised at 0.0 (Control), 0.5 (Low exercise) or 1.5 (Vigorous exercise) body lengths $\mathrm{sec}^{-1}$ for 32 days.

\begin{tabular}{lccc}
\hline Group & $\begin{array}{c}\text { Weight } \\
\text { Gain } \\
(\mathrm{gms})\end{array}$ & $\begin{array}{c}\text { Food } \\
\text { Eaten } \\
(\mathrm{gms})\end{array}$ & $\begin{array}{c}\text { Utilisation } \\
\left(1000^{*} \mathrm{wt} / \mathrm{food}\right)\end{array}$ \\
\hline Controls & 20.7 & 36 & 0.578 \\
Low Exercise & 58.2 & 40 & 1.437 \\
Vigorous Exercise & 14.5 & 30 & 0.480 \\
\hline
\end{tabular}

Liver weight (Fig. 2) and the hepatosomatic index (HSI) (Fig. 3) increased during the study. Following 32 days of prolonged exercise the fish of the low exercise group had significantly higher liver weight and HSI compared to the other two groups. Furthermore, the liver weight and the HSI in the low exercised fish after 32 days were significantly higher than pre-exercised values in this group.

As seen with the other parameters, fish experiencing 32 days of exercise at low level exhibit a significant increase in both total weight of mesenteric fat as well as in percentage mesenteric 


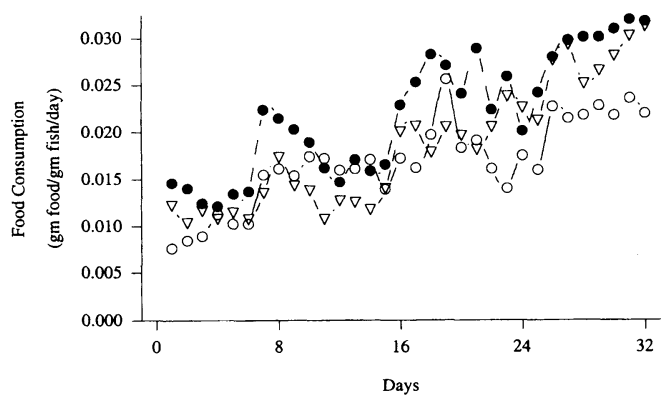

Figure 6. Food consumption (gram food consumed/gram fish/day) fitted curve. (O) Control group; (O) Low exercised trout; $(\nabla)$ Vigorously exercised trout.

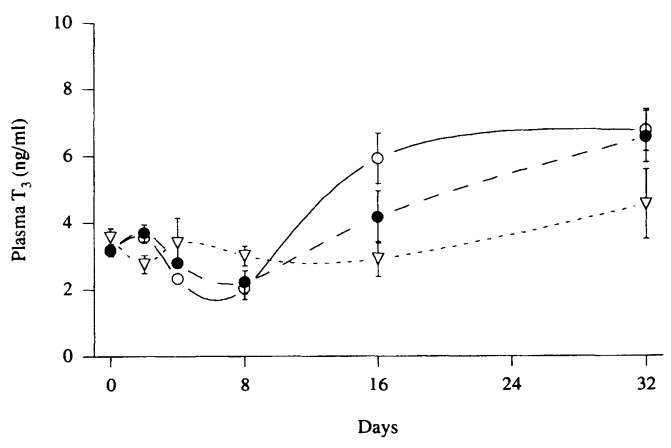

Figure 8. Plasma $\mathrm{T}_{3}$ (mean $\pm \mathrm{SEM}$ ). ( $\bigcirc$ ) Control group $(\mathrm{n}=8) ;(\bigcirc)$ Low exercised trout $(\mathrm{n}=8) ;(\nabla)$ Vigorously exercised trout $(n=8)$.

fat to body weight (Fig. 4 and 5). Mean values of both these parameters stayed level for the control fish, but those fish forced to swim at 1.5 BLS showed a large and significant decrease in this parameter at 16 days of exercise which was apparently restored by 32 days.

Appetite and food conversion was used as an indirect expression of growth response to exercise. The moderately exercised fish consumed more food than either the controls $(113 \%)$ or

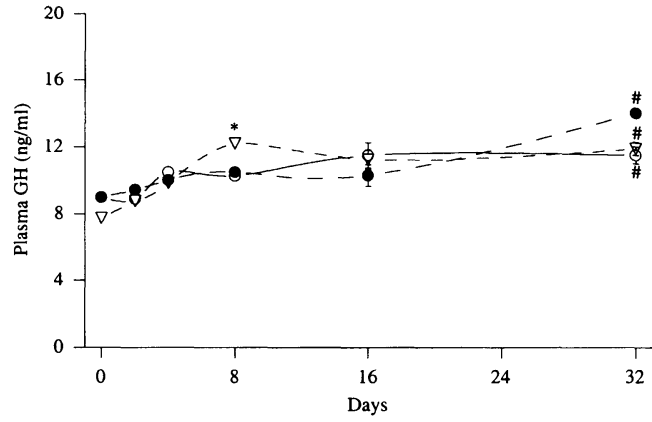

Figure 7. Plasma GH (mean \pm SEM). (O) Control group $(n=8) ;(\bigcirc)$ Low exercised trout $(n=8) ;(\nabla)$ Vigorously exercised trout $(\mathrm{n}=8)$. $\left({ }^{*}\right)$ Different from low exercised trout and control group. (\#) Represent a significant difference from Day 0 .

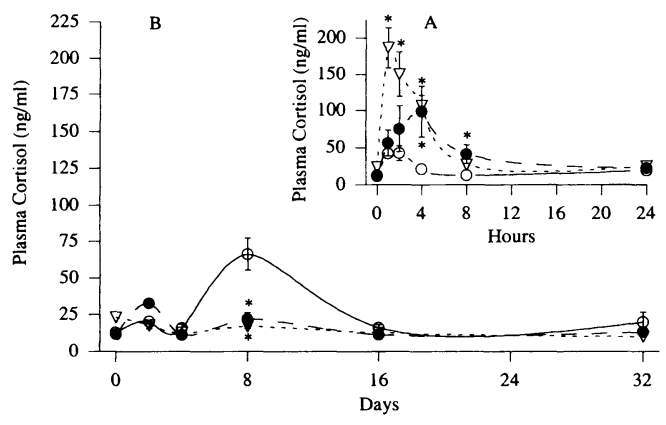

Figure 9. Plasma cortisol (mean \pm SEM). (A) Initial reactions. (B) Prolonged reactions (O) Control group $(\mathrm{n}=8) ;(\bigcirc)$ Low exercised trout $(\mathrm{n}=8) ;(\nabla)$ Vigorously exercised trout $(\mathrm{n}=8)$. $\left(^{*}\right)$ Different from control group.

the high exercise group (134\%) (Table 2). Furthermore, food conversion efficiency (defined as $1000 \mathrm{x}$ weight gain in grams/food consumed in grams) over the 32 days was some threefold greater for the fish exercised at 0.5 BLS. The fish forced to swim at 1.5 BLS, on the other hand, showed less appetite and lower feed conversion than did the controls. Calculation of food consumption revealed that fish swum at 1.5 BLS initially showed a decrease in appetite 


\section{Discussion}

Wootton (1990) defines appetite as "the quantity of food consumed before the fish ceases to eat voluntarily". The results from this study indicate that, for this stock of rainbow trout, low exercise increases both appetite $(\approx 13 \%)$ and the growth/food intake ratio or feed conversion ( $\approx$ threefold) over that of still-water controls or fish kept at 1.5 BLS. Thus leading to a significantly greater increase in weight gain than observed in the other 2 groups. Furthermore, the vigorously exercised fish exhibited both lower appetites and lower feed conversion than did the low exercised fish or the control fish. The less food taken by the vigorously exercised group suggests that the higher bioenergetic demands faced by these fish are, in some fashion, decreasing either appetite or feeding behaviour. It is possible that the additional effort of obtaining the food while maintaining position (or returning to position) somehow reduces the appetite in some way. These results are in accordance with earlier works which has reported that juvenile Atlantic salmon forced to exercise exhibited greater growth, food intake and food utilisation than did still-water controls (Jørgensen \& Jobling 1993, Jørgensen et al. 1996). In contrast fish swum at 2.0 BLS had lower values for these parameters than both controls and the other exercised groups. Besner (1980) also noted that increased water velocities did increase growth rates in juvenile coho salmon, and that further increase in water velocity (2.0 BLS) resulted in decreased growth rates. The rainbow trout used in this study were from a strain which had not been exposed to streaming water for some generations, and this may explain why lower growth was observed at relatively lower swimming speeds (1.5 vs. 2.0 BLS). On the other hand, there are probably real differences in the physical capabilities between various salmonid species, which would be reflected in their ability to enhance growth under different swimming regimes (White \& $L i$ 1985). Further, both species and size differences may have contributed to differences in growth response to exercise. (Beamish 1978, White \& Li 1985). The increase in liver weights during the study corresponds well with the increase in body weight.

The low exercised fish exhibited a significant increase in percentage of mesenteric fat after 32 days of swimming, both as total weight and as a percentage of body weight. Both the controls and the high-exercised fish also showed some increase in total mesenteric fat over the same period, but not when expressed as a percentage of body weight. Increase in lipid deposition in muscle during prolonged exercise has been observed in previous studies with brown trout (Davison \& Goldspink 1977) and brook trout (East \& Magnan 1987). To our knowledge, this is the first report of increased lipid deposition in mesenteric tissues during exercise of fish. These data suggest that ration was not limiting for any of the 3 groups and that lipid deposition continued even in the fish undergoing high exercise. The increase in mesenteric fat content in the low exercised fish probably contributed to the observed increase in condition factor. Increase in condition factor has previously been found in fish undergoing prolonged exercise. For example, Jørgensen \& Jobling (1993) noted that while the characteristic smoltification-associated decline in condition factor was seen in the control fish, all groups of Atlantic salmon undergoing forced exercise exhibited an increase in condition factor. In contrast, Kuipers (1982) reported that sustained exercise of postsmolt Atlantic salmon resulted in decrease in condition factor. The effects of exercise on condition factor may well depend upon species and especially life stage. It is apparent that much of the increase in mesenteric fat and condition factor occurred during the last sampling period (i.e. days 16 to 32 ). An extension of the swim- 


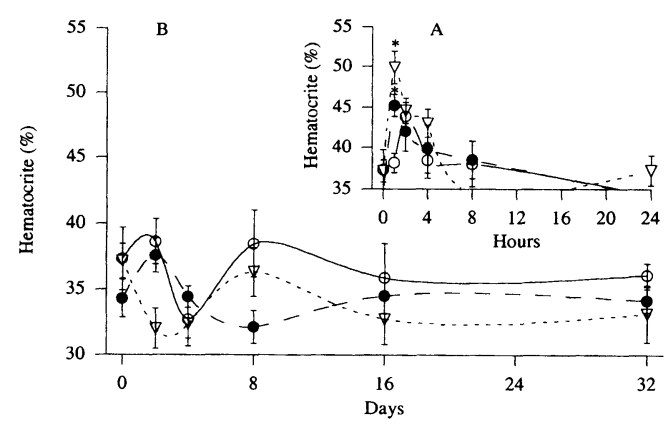

Figure 10. Hematocrit (mean $\pm \mathrm{SEM}$ ). (A) Initial reactions. (B) Prolonged reactions $(\mathrm{O})$ Control group $(\mathrm{n}=8)$; $(\bigcirc)$ Low exercised trout $(\mathrm{n}=8) ;(\nabla)$ Vigorously exercised trout $(n=8)$. $(*)$ Different from control group.

which at the end of the study increased dramatically to a level similar to the low exercised fish (Fig. 6).

There was a slight increase in the levels of plasma growth hormone during the study (Fig. 7). The mean concentrations in the 0.5 BLS fish after 32 days of continuous swimming were significantly elevated over pre-exercised values as well as at all other times this parameter was analysed for this group. The plasma GH level was also significantly higher in the $1.5 \mathrm{BLS}$ fish at 32 days than in the pre-exercised fish. However, none of the plasma $\mathrm{GH}$ values in the three groups were significantly different from each other at this time or any other time during the study, with the exception of a single peak in GH in the vigorously exercised fish on day 8 . (Note: Plasma GH was not determined over the initial $24 \mathrm{~h}$ of the study due to previous commitments of the plasma).

The plasma levels of $\mathrm{T}_{3}$ in the exercised groups and the control group showed a non-significant increase during the study (Fig. 8). The non-exercised group had a more rapid elevation in plasma $T_{3}$ than both exercised groups. Between the exercised groups the low exercised group had the fastest elevation in T3 during the experiment.

The greatest impact of exercise was seen for cortisol (Fig. 9), which rose in all 3 groups following the start of the experiment. In the control fish, increase in plasma cortisol was very slight and short (presumably due to sampling stress), with the only significant different values seen at $1 \mathrm{~h}$ (higher than both 0 and $8 \mathrm{~h}$ ). In the group of fish forced to swim 1.5 BLS, there was an extremely high and significant increase in plasma cortisol within $1 \mathrm{~h}\left(186.25 \mathrm{ng} \mathrm{ml}^{-1}\right.$ vs. $23.13 \mathrm{ng} \mathrm{ml}^{-1}$ at time 0 ). The plasma cortisol levels continued to be significantly elevated and higher than both control and low exercise fish at 2 and $4 \mathrm{~h}$ post-onset. After $8 \mathrm{~h}$ the plasma cortisol concentration had returned to normal post experimental values. Plasma cortisol levels also rose in the low exercise fish after the onset of exercise, but only the concentrations at the 4 and $8 \mathrm{~h}$ sampling periods were significantly higher than in the controls. Plasma cortisol levels had returned to pre-exercise levels within 24 $h$ of the onset of exercise, and there were no apparent effects of exercise on plasma cortisol levels during the rest of the study. There was a large but not readily explained significant peak in plasma cortisol levels in the control group of fish at the 8 day mark.

Hematocrits increased significantly within $1 \mathrm{~h}$ at the onset of exercise in both the low and vigorously exercised groups (Fig. 10). Furthermore, the increase in hematocrit in the vigorously exercised fish was significantly higher than the increase seen in the low exercised fish. By $8 \mathrm{~h}$ of exercise, the hematocrit values in all 3 groups had returned to pre-exercise values, where they remained till the end of the study. There were no changes in plasma glucose concentrations associated with either exercise or sampling throughout the 32 days of exercise, although the vigorously exercised group consistently exhibited higher mean values (data not shown). 
ming regime over another sampling period may have shed further light on these results.

The results from the present study show that neither plasma $\mathrm{GH}$ or plasma $\mathrm{T}_{3}$ were elevated in rainbow trout during the 32 days of continuous exercise at either low or vigorous rates. Forsman \& Virtanen (1989) found that in smolting Atlantic salmon, exercise (2.5 BLS) led to a transient increase in plasma thyroxine, which had returned to normal levels within $12 \mathrm{~h}$ of onset. Based on similar changes in plasma cortisol, the authors concluded that at this speed the fish were primarily swimming anaerobically and, particularly for the precocious males, under some stress (Forsman \& Virtanen 1989). In a companion study utilising the same system, same strain of rainbow trout and similar water velocities as in the current one, a non-significant increase in circulating $\mathrm{T}_{3}$ levels over $24 \mathrm{~h}$ of exercise were noted (Nielsen et al. 1994). Consequently there seems to be no obvious relationship between the described increase in growth observed in the exercising salmonids and the plasma levels of these hormonal factors. A possible explanation for the observed increase in plasma $T_{3}$ in the low exercised group and the still-water group could be the higher food consumption in these groups, as a close connection between increased food intake and elevated plasma $\mathrm{T}_{3}$ levels has been reported (Eales 1988, Sweeting \& Eales 1992).

The studies of Barrett \& McKeown (1988) and Kakizawa et al. (1995) demonstrated increase in plasma growth hormone concentration within 5-10 min post-exercise if fish had been exercised for at least $4 \mathrm{~h}$ (Barrett \& McKeown 1988). The exercise-associated increase in plasma GH was not seen during exercise, but rather after exercise had ceased. Nielsen et al. (1994) found a single transient peak in plasma $\mathrm{GH}$ within $2 \mathrm{~h}$ of onset of vigorous exercise (1.5 BLS), whereas no such peak was observed in the low exercised (0.5 BLS) fish. It should be noted that the post-exercise increases in plasma GH demonstrated by Barrett \& McKeown (1988) were observed within 10 min of exercise stoppage and had returned to normal levels within $2 \mathrm{~h}$. The prolonged effects of exercise on the plasma levels of growth hormone seem to be a slight elevation during the experiment. Altogether, low exercise appears to form a favorable condition for growth in accordance with numerous experiments, as reviewed by Björnsson (1997).

Plasma cortisol levels also exhibited a transient increase at the onset of exercise, the magnitude of which appeared to be dependent on the speed of swimming. The levels of circulating cortisol in both of the exercised groups returned to basal values within a very short time, and did not appear to be further affected by continued exercise. The lack of change in plasma glucose may support the contention that plasma cortisol titers are not changed by exercise per se. Transient increases in hematocrit following physical stress have been reported previously (Soivio \& Oikari 1976, Barton et al. 1987), lending further support to the hypothesis that it was the onset of exercise that stimulated the cortisol response rather than the exercise per se.

\section{Conclusion}

In conclusion, the results of this study demonstrate that low exercise $(0.5$ BLS) over a prolonged period can induce increased growth, whereas exercise at higher levels may inhibit growth, possibly via increased bioenergetic demands (Kiessling et al. 1994). The increase in growth were achieved by an increase in both appetite and food conversion efficiancy. The results suggest that exercise-induced weight gain can occur in the absence of an obvious increase in circulating levels of growth hormone. Plasma $\mathrm{T}_{3}$ levels, on the other hand, seemed to be more influenced by food intake than watercurrent. Plasma cortisol did not appear to be af- 
fected by exercise per se, except for the onset of exercise at which time both cortisol and growth hormone levels showed transient increase.

\section{Acknowledgements}

Natural Sciences and Engineering Research Council of Canada grant A9434 awarded to Brian A. McKeown supported this study.

\section{References}

Barrett BA, McKeown BA: Sustained exercise increases plasma growth hormone concentrations in two anadromous salmonids. Can. J. Fish. Aquat. Sci. 1988, 45, 747-749.

Barton BA, Schreck CB, Barton LD: Effect of chronic cortisol administration and daily acute stress on growth, physiological conditions, and stress responses in juvenile rainbow. Dis. Aquat. Org. 1987, 2, 173-185.

Beamish F.W.H: Swimming capacity. In: Fish Physiology, vol. VII. W.S. Hoar and D.J. Randall, eds., Academic Press, New York . 1978.

Besner M: Endurance training: an affordable rearing strategy to increase food conversion efficiency, stamina, growth and survival of coho salmon smolts (Oncorhynchus kisutch). Ph.D dissertation, University of Washington, Seattle. 1980.

Björnsson BT: The biology of growth hormone: from daylight to dominance. Fish Physiol. Biochem. 1997, 17, 9-24.

Boesgaard L, Nielsen ME and Rosenkilde P: Moderate exercise decreases plasma cortisol levels in Atlantic salmon (Salmo salar). Comp. Biochem. Physiol. 1993, 106A, 641-643.

Christiansen JS, Jobling M: The behaviour and the relationship between food intake and growth of juvenile Arctic charr, Salvelinus alpinus L., subjected to sustained exercise. Can. J. Zool. 1990, 68, 2185-2191.

Davison $W$ : The effect of exercise training on teleost fish, a review of recent literature. Comp. Biochem. Physiol. 1977, 117A, 67-75.

Davison $W$, Goldspink $G$ : The effect of prolonged exercise on the lateral musculature of the brown trout (Salmo trutta). J. Exp. Biol. 1977, 70, 1-12.

Eales JG: The peripheral metabolism of thyroid hormones and regulation of thyroidal status in poikilotherms. C. J. Zool. 1985, 63, 1217-1231.

Eales JG: The influence of nutritional state of thyroid function in various vertebrates. Am. J. Zool. $1988,28,351-362$.
East P, Magnan P: The effect of locomotor activity on the growth of the brook charr, Salvelinus fontinalis Mitchill. Can. J. Zool. 1987, 65, 843-846.

Forsman L, Virtanen E: Responses of juvenile and sexually mature two-summer-old salmon (Salmo salar) to prolonged swimming. Aquaculture. 1989, 82, 245-255.

Foster AR, Houlihan DF, Gray C, Medale F, Fauconneau B, Kaushik SJ, Le Bail PY: The effects of ovine growth hormone on protein turnover in rainbow trout. Gen. Comp. Endocrinol. 1991, 82, 11-120.

Gill JA, Sumpter JP, Donaldson EM, Dye HM, Souza $L$, Berg T, Wypych J, Langley $K$ : Recombinant chicken and bovine growth hormones accelerate growth in aquacultured juvenile Pacific salmon Oncorhynchus kisutch. Biotechnology. 1985, 3, 643-646.

Higgs DA, Fagerlund UHF, McBride JR, Dye HM, Donaldson EM: Influence of combinations of bovine growth hormone, 17a-methyltestosterone, and L-thyroxine on growth of yearling coho salmon (Oncorhynchus kisutch). Can. J. Zool. 1977, 55, 1048-1056.

Houlihan DF, Laurent $P$ : Effects of exercise training on the performance, growth, and protein turnover of rainbow trout (Salmo gairdneri). Can. J. Fish. Aquat. Sci. 1987, 44, 1614-1621.

Johnston IA, Moon TW: Exercise training in skeletal muscle of brook trout (Salvelinus fontinalis). J. Exp. Biol. 1980, 87, 177-194.

Jørgensen EH, Jobling M: The effects of exercise on growth, food utilisation and osmoregulatory capacity of juvenile Atlantic salmon. Aquaculture. 1993, 116, 233-246.

Jørgensen EH, Baardvik BM, Eliassen R, Jobling M: Food acquisition and growth of juvenile Atlantic salmon (Salmo salar) in relation to spatial distribution of food. Aquaculture. 1996, 143, 277-289.

Kakizawa S, Kaneko T, Hasegawa S, Hirano T: Effects of feeding, fasting, background adaptation, acute stress and exhaustive exercise on the plasma somatolactin concentrations in rainbow trout. Gen. Com. Endocrinol. 1995, 98, 137-146.

Kiessling A, Higgs DA, Dosanjn BS, Eales JG: Influence of sustained exercise of two ration levels on growth and thyroid function of all-female Chinook salmon (Oncorhynchus tshawytscha) in seawater. Can. J. Fish. Aquat. Sci. 1994, 51, 1975-1984.

Kuipers $J$ : Salmon thrive on exercise. Fish Farmer. 1982, 5, 9-10. 
Leon $K A$ : Effect of exercise on feed consumption, growth, food conversion, and stamina of brook trout. Progressive Fish-Culturist. 1986, 48, 4346.

McKeown BA, Leatherland JF, John TM: The effect of growth hormone and prolactin on the mobilization of free fatty acids and glucose in the kokanee salmon, Oncorhynchus nerka. Comp. Biochem. Physiol. 1975, 50B, 425-430.

McKinnon DL, Farrell AP: The effect of 2-(thiocyanomethylthio)-benzothiazole on juvenile coho salmon (Oncorhynchus kisutch): sublethal toxicity testing. Environ. Toxicol. Chem. 1992, 11, 1541-1548.

McLean E, Donaldson EM, Dye HM, Souza LM: Growth acceleration of coho salmon (Oncorhynchus kisutch) following oral administration of recombinant bovine somatotropin. Aquaculture. 1990, 91, 197-203.

MacLatchy DL, Kawauchi H, Eales JG: Stimulation of hepatic thyroxine 5'-deiodinase activity in rainbow trout by Pacific salmon growth hormone. Comp. Biochem. Physiol. 1992, 101A, 689-691.

Moav B, McKeown BA: Thyroid hormones increases transcription of growth hormone mRNA in rainbow trout. Hormon. Metabolic Res. 1992, 24, 1014

Mommsen TP, Vijayan MM, Moon TW: Cortisol in teleosts: Dynamics, Mechanisms of action, and metabolic regulation. Rev. Fish Biol. 1999, 9, 211-268

Nielsen ME, Boesgaard L, Sweeting RM, McKeown $B A$, Rosenkilde P: Plasma levels of lactate, potassium, glucose, cortisol, growth hormone, and triiodo-L-thyronine in rainbow trout (Oncorhynchus mykiss) during exercise at various levels for 24 h. Can. J. Zool. 1994, 72, 1643-1647.

Pickering AD: Progress in Comparative Endocrinology, Wiley-Liss, Inc. 1990, 473-471.

Postlethwait EK, McDonald DG: Ion regulation during exercise and stress in freshwater rainbow trout (Oncorhynchus mykiss). J. Exp. Biol. 1995, 198, 295-304.

Sheridan MA: Effects of thyroxine, cortisol, growth hormone and prolactin on lipid metabolism of coho salmon, Oncorhynchus kisutch, during smoltification. Gen. Comp. Endocrinol. 1986, 64, 220-238.

Sheridan MA: Regulation of lipid metabolism in poikilothermic vertebrates. Comp. Biochem. Physiol. 1994, 107, 495-508.

Soivio A, Oikari A: Hematological effects of stress on teleost, Esox lucius L. J. Fish Biol. 1976, 8, 397 411.

Sweeting RM, Wagner GF, McKeown BA: Changes in plasma glucose, amino acid nitrogen and growth hormone during smoltification and seawater adaptation in coho salmon, Oncorhynchus kisutch. Aquaculture. 1985, 45, 185-197.

Sweeting RM, Eales JG: The effects of fasting and feeding on hepatic thyroxine '5-monodeiodinase activity in rainbow trout, Oncorhynchus mykiss. Can. J. Zool. 1992, 70, 1516-1522.

Totland GK, Kryvi H, Jødestøl KA, Christiansen EN, Tangerås A, Slinde E: Growth and consumption of the swimming muscle of adult Atlantic salmon, Salmo salar L., during long-term sustained swimming. Aquaculture. 1987, 66, 299-313.

Walker $M G$, Emerson $L$ : Sustained swimming speeds and myotomal muscle function in trout, Salmo gairdneri. J. Fish Biol. 1978, 13, 475-481.

Weatherley AH, Gill HS: Influence of bovine growth hormone on the growth dynamics of mosaic muscle in relation to somatic growth of rainbow trout, Salmo gairdneri Richardson. J. Fish Biol. 1982, 20, 165-172.

Weatherley AH, Gill HS: The biology of fish growth. Academic Press, London and San Diego. 1989, 177-208.

White JR, Li HW: Determination of the energetic cost of swimming from the analysis of growth rate and body composition in juvenile chinook salmon, Oncorhynchus tshawytscha. Com. Biochem. Physiol. 1985, 81, 25-33.

Wootton JR: Ecology of Teleost Fishes. Chapman and Hall, London. 1990, 404.

\section{Sammendrag}

Fysiologiske og hormonelle andringer som følge af vedvarende svømning hos regnbueørred (Oncorhynchus mykiss) opdrattet i akvakultur.

Regnbueørred (Oncorhynchus mykiss) blev udsat for tre niveauer af vedvarende svømning, hurtig (1,5 kropslængder $\left.\mathrm{s}^{-1}\right)$, moderat $\left(0,5\right.$ kropslængder $\left.\mathrm{s}^{-1}\right)$ og ingen $\left(0,0\right.$ kropslængder $\left.\mathrm{s}^{-1}\right)$, for at sammenligne fysiologiske og hormonelle aspekter af vækst hos ørred ved forskellige svømmehastigheder. Hematokrit og plasmaniveauer af glukose, væksthormon (GH), cortisol og triiodo-L-thyronine $\left(\mathrm{T}_{3}\right)$ blev moniteret ved begyndelsen af eksperimentet, efter 24 timer og efter $2,4,8,16$, og 32 dages vedvarende svømning. Såvel fødeindtag som morfologiske parametre blev under- 
søgt. Ved forsøgets afslutning havde de moderat svømmende ørreder en signifikant $(p<0,05)$ højere vægtforøgelse sammenlignet med både kontrolfiskene og de hurtigt svømmende fisk. De moderat svømmende ørredder konsumerede også mere foder end de to andre grupper. Hematokritniveauerne steg signifikant $\mathrm{i}$ både de hurtigt og moderat svømmende fisk ved forsøgets igangsættelse, men returnerede til start niveauet indenfor 8 timer. Starten af svømmeregimet forhøjede plasmaniveauet af glukose, men glukose niveauet syntes herefter ikke at være influeret af svømningen. Ligeledes var plasmakoncentrationerne af både $\mathrm{GH}$ og $\mathrm{T}_{3}$ ikke direkte berørt af svømmeregimet, men indirekte som følge af det ændrede fødeindtag. Plasmacortisolkoncentrationen steg proportionalt med niveauet af svømning i forbindelse med igangsættelsen af svømmeregimet. Plasma cortisolniveauet returnerede til begyndelsesniveauet indenfor 24 timer og vedvarende svømning havde ikke nogen efterfølgende effekt på cortisolniveauet. Resultaterne fra dette eksperiment viser, at starten på et svømmeregime medfører talrige ændringer i plasmakomponenterne, samt at den observerede vægtforøgelse ikke skyldes forhøjede plasmaniveauer af $\mathrm{GH}$ og $\mathrm{T}_{3}$.

(Received April 8, 1999; accepted February 18, 2000).

Reprints may be obtained from: M. E. Nielsen, Department of Veterinary Microbiology, Section of Fish Diseases, The Royal Veterinary and Agricultural University, Stigbøjlen 4, DK-1870 Frederiksberg C, Denmark. E-mail: men@kvl.dk, tel: +45352827 03, fax: +4535282711. 